\title{
Caffeine intake in a representative sample of Irish adults aged 18-64 years
}

\author{
K. Evans, J. Walton and A. Flynn \\ School of Food and Nutritional Sciences, University College Cork, Cork, Republic of Ireland.
}

Caffeine occurs naturally in foods such as tea, coffee and chocolate and is also added to some foods and beverages. In recent years there has been concern regarding the possible adverse health effects of high caffeine intakes ${ }^{(1)}$. According to the European Food Safety Authority (EFSA) single doses of caffeine up to $200 \mathrm{mg}$ and habitual caffeine consumption of up to $400 \mathrm{mg} / \mathrm{d}$ do not give rise to safety concerns for non-pregnant adults ${ }^{(1)}$. The objective of this analysis was to estimate caffeine intake in the Irish adult population, based on nationally representative data collected in the National Adult Nutrition Survey (NANS) (2008-2010) (www.iuna.net) ${ }^{(2)}$. A 4 day semi-weighed food record was used to collect food and beverage intake data. Caffeine containing foods such as tea, coffee, chocolate and carbonated beverages were assigned a caffeine value using data provided by EFSA ${ }^{(3)}$. Brand level data were used to assign caffeine values to additional beverages e.g. energy drinks. For these analyses, caffeine in nutritional supplements has not been accounted for. Almost all $(97 \%)$ of NANS participants aged 18-64 years consumed food/beverages containing caffeine during the recording period. The mean daily intake (MDI) of caffeine in the total population $(\mathrm{n}=1274)$ was $102 \mathrm{mg} / \mathrm{d}$. Among consumers, the MDI of caffeine was $104 \mathrm{mg} / \mathrm{d}\left(108 \mathrm{mg} / \mathrm{d}\right.$ men; $101 \mathrm{mg} / \mathrm{d}$ women) and intakes were highest in adults aged 36-50 years (127 mg/d). The $\mathrm{P}_{95}$ intake of caffeine did not approach $400 \mathrm{mg} / \mathrm{d}$ for any group.

Mean daily intake of caffeine and intake of caffeine per consumption occasion in Irish adult caffeine consumers aged 18-64 years

\begin{tabular}{|c|c|c|c|c|c|c|}
\hline \multirow[b]{2}{*}{ Group } & \multirow[b]{2}{*}{ No of subjects } & \multicolumn{2}{|c|}{ Mean daily intake (mg/d) } & \multirow[b]{2}{*}{ No of occasions } & \multicolumn{2}{|c|}{ Intake per occasion (mg) } \\
\hline & & Mean & $\mathrm{P}_{95}$ & & Mean & $\mathrm{P}_{95}$ \\
\hline$\overline{\text { All }}$ & 1242 & 104 & 280 & 13347 & 39 & 108 \\
\hline $\begin{array}{l}\text { Male } \\
\text { Female }\end{array}$ & $\begin{array}{l}610 \\
632\end{array}$ & $\begin{array}{l}108 \\
101\end{array}$ & $\begin{array}{l}297 \\
258\end{array}$ & $\begin{array}{l}6291 \\
7056\end{array}$ & $\begin{array}{l}42 \\
36\end{array}$ & $\begin{array}{l}117 \\
104\end{array}$ \\
\hline $\begin{array}{l}18-35 y \\
36-50 y \\
51-64 y\end{array}$ & $\begin{array}{l}510 \\
429 \\
303\end{array}$ & $\begin{array}{r}79 \\
127 \\
115\end{array}$ & $\begin{array}{l}242 \\
332 \\
287\end{array}$ & $\begin{array}{l}4368 \\
5211 \\
3768\end{array}$ & $\begin{array}{l}37 \\
42 \\
37\end{array}$ & $\begin{array}{l}108 \\
113 \\
104\end{array}$ \\
\hline
\end{tabular}

There were over 13,000 caffeine consumption occasions during the course of the survey and the mean caffeine intake per occasion was $39 \mathrm{mg}$. The $\mathrm{P}_{95}$ intake of caffeine per consumption occasion did not approach $200 \mathrm{mg}$ for any group. Among caffeine consumers, coffee $(53.5 \mathrm{mg})$ and teas $(41.6 \mathrm{mg})$ were the main contributors to caffeine intake, with carbonated beverages $(5.3 \mathrm{mg})$, chocolate $(2.0 \mathrm{mg})$ and energy drinks $(1.9 \mathrm{mg})$ contributing lower amounts. These analyses indicate that, even among high consumers, levels of habitual caffeine consumption and intakes of caffeine as a single dose in Irish adults do not give rise to safety concerns.

This research was funded by the Department of Agriculture, Food and the Marine under the "Food for Health Research Initiative" (FHRI) 2007-2012.

1. European Food Safety Authority (EFSA) (2015) Scientific Opinion on the safety of caffeine.

2. Walton J (ED) 2011 National Adult Nutrition Survey- Summary Report Available online at http://www.iuna.net.

3. European Food Safety Authority (EFSA) (2014) Gathering consumption data on specific consumer groups of energy drinks. 